\title{
Coastal storms risk assessment for Mamaia and Eforie barriers
}

\author{
Mădălina Ristea, Florin Tătui \\ Faculty of Geography \\ University of Bucharest \\ Bucharest, Romania
}

\begin{abstract}
The level of damage for Mamaia and Eforie Barriers shows that in a risk assessment to coastal storms, more important than the inundation limit is, in fact, the density of elements (buildings, roads, etc.) that can be affected.
\end{abstract}

Keywords - coastal storms; inundation scenarios; risk assessment

\section{INTRODUCTION}

Storms are a major threat for the large number of people living in coastal areas. The rapid climate change has led to intensified coastal storms throughout the world, resulting in extreme damage to households and even loss of human lives. This is the main reason for the increasing interest in risk assessment and disaster risk reduction measures in the last decade.

This paper aims to assess the risk to coastal storms for two vulnerable sectors of the Romanian Black Sea coast Mamaia and Eforie barriers. These sectors represent very important touristic areas, with valuable infrastructure, which can be highly affected in the event of a major storm. We focused our analysis on the risk of buildings and infrastructure, excluding the potential loss of human lives because we considered that a major storm is most likely to occur in the active season (winter season), when the number of tourists on the two barriers is low.

\section{Methodology}

The methodology is based on three scenarios: the impact of low storms (significant wave height of $2.5 \mathrm{~m}$ ), severe storms (significant wave height of $5 \mathrm{~m}$ ) and extreme storms (significant wave height of $7 \mathrm{~m}$ ). We calculated the maximum horizontal distance that storm waves can reach on the beach in order to establish the inundation limits (computed by the ratio between wave run-up and foreshore slope) for each scenario.

First, we computed wave run-up level (measured vertically from the waterline) for all three scenarios using the approach proposed in [1]:

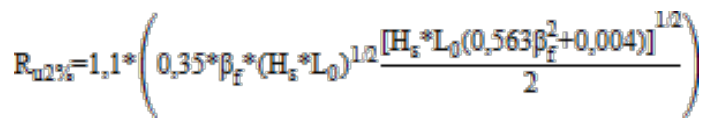

where $\beta_{\mathrm{f}}$ is the foreshore beach slope defined over the area of significant swash activity, $\mathrm{H}_{\mathrm{s}}$ is the significant wave height and $L_{0}$ is the offshore wave length, which can be expressed as $\mathrm{L}_{0}=\mathrm{gT}^{2} / 2 \pi$. In order to determine the horizontal distance of wave run-up on the beach, we used the equation proposed in [2]:

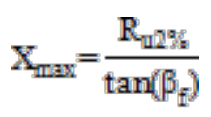

where $R_{u 2 \%}$ is the $2 \%$ exceedance level for run-up peaks on natural beaches and $\beta_{\mathrm{f}}$ is the foreshore beach slope.

For determining the water levels in the point of maximum run-up and of flow velocities on the beach we made a medium profile for each barrier, by interpolating 15 different profiles for Mamaia Barrier and 4 for Eforie Barrier. After that we established the highest point on each beach in order to compute the overwash extension. The water level at the top of the above mentioned point can be obtained using the approach proposed in [3]:

$$
\mathrm{h}=\frac{\tan \beta_{\mathrm{w}} \mathrm{x}_{\mathrm{C}}}{\mathrm{x}_{\mathrm{R}} \cos \beta}\left(\mathrm{x}_{\mathrm{R}}-\mathrm{x}_{\mathrm{C}}\right)
$$

where: $X_{R}$ is the horizontal distance of wave run-up on the beach (the same as $X_{\max }$ ), $X_{c}$ is the distance from the still water line to the highest point on the beach, $\beta$ is the beach slope and $\tan \beta_{\mathrm{w}}$ is a constant $(0,035)$.

The flow velocities were computed using the equation proposed in [4]:

$$
\mathrm{u}=0,66 \sqrt{\mathrm{gh}}
$$

where: $\mathrm{g}$ is the gravitational acceleration and $\mathrm{h}$ is the water level at the highest point on the beach.

Knowing the two values, water level and velocity, we were able to determine the inundation rate for each barrier (Tab. I). 
TABLE I. INUNDATION RATES FOR MAMAIA AND EFORIE BARRIERS

\begin{tabular}{|c|c|c|c|}
\hline & $\begin{array}{c}\text { Water } \\
\text { level/Depth } \\
\text { (m) }\end{array}$ & $\begin{array}{c}\text { Velocity } \\
\text { (m/s) }\end{array}$ & $\begin{array}{c}\text { Depth-Velocity } \\
\text { Product }\left(\mathbf{m}^{2} / \mathbf{s}\right)\end{array}$ \\
\hline $\begin{array}{c}\text { Mamaia } \\
\text { Barrier }\end{array}$ & 1.081 & 2,148 & 2.323 \\
\hline $\begin{array}{c}\text { Eforie } \\
\text { Barrier }\end{array}$ & 1.890 & 2.841 & 5.370 \\
\hline
\end{tabular}

Based on this methodology and on the results, we could assess the risk for each building and for infrastructure inside the inundation limits of each scenario. This way, we have obtained a comprehensive database containing information like: type of building, type of use, year of construction, surface, materials they were made of, market value, etc.

\section{RESULTS}

The inundation limits range between approximately 25 $\mathrm{m}$ for low storms (26.53 m for Eforie Barrier and $24.28 \mathrm{~m}$ for Mamaia Barrier), $90 \mathrm{~m}$ for severe storms (90.75 m for Eforie Barrier and $88.01 \mathrm{~m}$ for Mamaia Barrier) and $190 \mathrm{~m}$ for extreme storms (193.87 m for Eforie and $194.73 \mathrm{~m}$ for Mamaia) (Fig. 1 and 2). Taking into consideration the good correlation between risk degree and barrier width, for Eforie Barrier, characterized by lower widths, the inundation limit for extreme storms exceeds in some places its width, affecting not only all the buildings, but also important infrastructure that connects the northern part of the coast with the southern one. Being almost double in size, Mamaia Barrier does not experience the same problems, but the high density of buildings increases its risk. In the case of low storms, only unanchored wooden structures could be affected, while for severe storms they would be totally damaged. Anchored wooden structures would only be partially damaged during severe storms and totally destroyed in case of an extreme storm, while concrete and brick structures could be partially affected on the ground floor in the worst case scenario (an extreme storm) (Table II.).

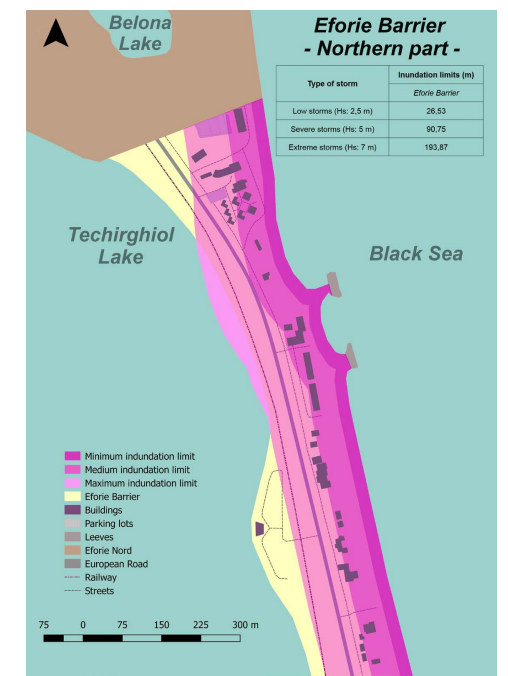

Fig.1. The inundation limits on Eforie Barrier
For the risk assessment, we only considered the limit for extreme storms for both barriers. Because the value per square meter is different along Mamaia Barrier, we had to divide it in 5 areas: area A1 - situated between Tăbăcărie Lake and Melody Bar, A2 - between Melody Bar and Rex Hotel, B1 - between Rex Hotel and “At the Barrels”, B2 between "At the Barrels" and Summerland rezidential area and B3 - between Summerland and the northern limit of the barrier [5] (B3 area - Fig.2). Overlaying the maximum inundation limit over the buildings we were able to extract the ones that could be inundated during an extreme storm. A number of 218 buildings on Mamaia Barrier and 50 on Eforie Barrier could be inundared during a major event (Table III.). After calculating a mean area for the buildings and extracting the mean values per square meter from [5], we could determine the mean value of the losses on the two barriers: 108.382.802 € for Mamaia Barrier and 7.582.700 € for Eforie. The latter is crossed by a road and a railway of national importance, both affected by the event, with a value of $13.780 .840 €$ (of which 7.840.000 $€$ for $2 \mathrm{~km}$ of road and $5.940 .840 €$ for $1.597 \mathrm{~km}$ of railway) according to [6]. This means that the value of losses for Eforie Barrier is 21.363.540 $€$, for both buildings and infrastructure.

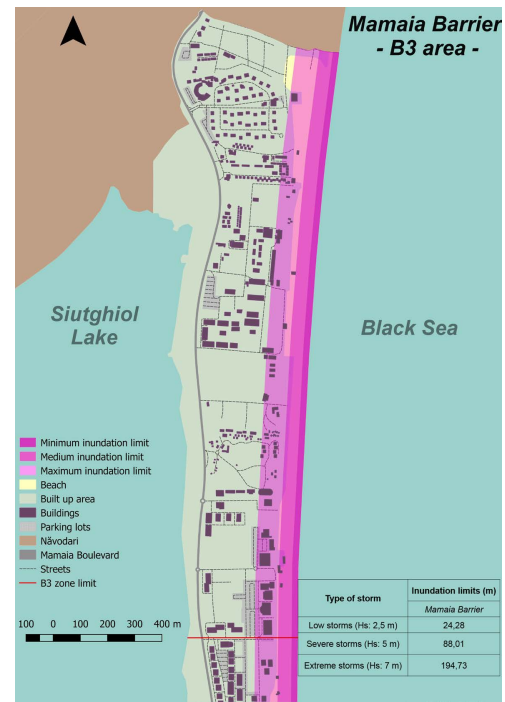

Fig. 2. The inundation limits on Mamaia Barrier

\section{CONCLUSIONS}

Even though, at first all tend to assume that, because the limit of Eforie Barrier is exceeded, the risk should be higher, in fact, the most important variable is the percentage of buildings or things that could be affected. Although the losses are much smaller than on Mamaia Barrier, the disruption between the northern and the southern part of the coastal area deriving from the inundation of the road and the railway, affects not only the barrier, but also all the communities located south. This 
type of assessment can be a starting point for disaster risk reduction measures and better management strategies that can diminish the potential losses on Mamaia and Eforie barriers in case of severe and extreme storms. Another gain from risk assessment analysis should be the awareness of all the problems that coastal communities will have to face due to climate change.

TABLE II ${ }^{\mathrm{a}}$. DEGREE OF DAMAGE BASED ON THE INUNDATION RATES

\begin{tabular}{|c|c|c|c|}
\hline & \multicolumn{3}{|c|}{ Depth-Velocity Product (ms) } \\
\hline House type & Inundation & Partial damage & Total damage \\
\hline Wood - Framed: Unanchored & $0-1,99$ & $2-2,99$ & $3->7$ \\
\hline Wood - Framed: Anchored & $0-2,99$ & $3-6,99$ & $>7$ \\
\hline Masonry, concrete and brick & $0-2,99$ & $3-6,99($ if $\mathrm{v}$ is also $\geq 2 \mathrm{~m} / \mathrm{s})$ & $>7$ (if $\mathrm{v}$ is also $\geq 2 \mathrm{~m} / \mathrm{s})$ \\
\hline
\end{tabular}

aTable modified after [7]

TABLE III. POTENTIAL LOSSES PRODUCED BY AN EXTREME STORM ON THE TWO BARRIERS

\begin{tabular}{|c|c|c|c|c|c|c|}
\hline & \multicolumn{7}{|c|}{ Mamaia Barrier } & \multirow{2}{*}{ Eforie Barrier } \\
\cline { 2 - 7 } & A1 area & A2 area & B1 area & B2 area & B3 area & \\
\hline No. of buildings affected & 61 & 42 & 21 & 21 & 73 & 50 \\
\hline Mean area per building (m) & 1.121 & 899 & 1.955 & 598 & 388 & 382 \\
\hline Mean value per m ${ }^{2}(€)$ & 578 & 616 & 568 & 554 & 541 & 397 \\
\hline Mean price per building (€) & 647.938 & 553.784 & 1.110 .440 & 331.292 & 209.908 & 151.654 \\
\hline Mean price per area (€) & 39.524 .218 & 23.258 .928 & 23.319 .240 & 6.957 .132 & 15.323 .284 & 7.582 .700 \\
\hline
\end{tabular}

\section{REFERENCES}

[1] H.F. Stockdon, R.A. Holman, P.A. Howd, and A.H. Sallenger, "Empirical parameterization of setup, swash and run-up", Coastal Engineering, vol. 53, no. 7, pp. 573-588, 2006.

[2] G. Di Paola, P.P.C. Aucelli, G. Benassai, and G. Rodriguez, "Coastal vulnerability to wave storms of Sele littoral plain (southern Italy)”, Natural Hazards, vol. 71, pp. 1795-1819, 2014.

[3] H. Schuettrumpf and H. Oumeraci, "Layer thicknesses and velocities of wave overtopping flow at seadikes", Coastal Engineering, vol. 52, pp. 473-495, 2005.
[4] H. Matsutomi, K. Okamoto, and K. Harada, "Inundation flow velocity of tsunami on land and its practical use”, Coastal Engineering Proceedings, vol.2, pp. 860-870, 2010.

[5] Rosa Trade International, "Market research on recorded minimum values of property in Constanța County," 2016.

[6] Ministry of Transport, “General Master Plan for Transport,” 2015.

[7] T. Karvonen, A. Hepojoki, H.K. Huhta, and A. Louhio, “The use of physical models in dam-break analysis,” RESCDAM Final Report, Helsinki University, 2000. 